\title{
WASHINGTON HOTLINE
}

Carol C. Henderson

Deputy Director, ALA Washington Office

(202)547-4440; (ALA0025)

NTIS. The Department of Commerce announced plans to issue a request for proposals to privatize the National Technical Information Service (NTIS) in the January 6 Commerce Business Daily. The Department intends to privatize the NTIS functions under the Federal Employee Direct Corporate Stock Ownership Plan (Fed Co-Op) concept, under which federal employees would exchange their government jobs for salaried positions with a contractor and be provided stock in the new firm. A conference with potential bidders took place January 29; an RFP was to be released within the month with a 30- to 45-day period for submission of bids.

NTIS privatization is on a fast track, despite the fact that both House and Senate have prohibited further contracting out by NTIS in separate legislation. However, final legislative action has not taken place on either the House-passed HR 2160, the National Bureau of Standards Authorization Act, nor the Senate-passed trade bill, HR 3 (S. 1420). An October 1986 Commerce Department report, "Privatization Proposal for the National Technical Information Service," concluded that extensive privatization would present substantial "policy costs and risks, those associated with U.S. competitiveness, national security, technology transfer, intellectual property rights and the availability of scientific and technical information."

The House Science, Research, and Technology Subcommittee, which held hearings on this issue last year, scheduled a new hearing for February 24. Legislators, especially those on science committees, should be urged to take final action quickly to prohibit further contracting out of NTIS.

GPO. The Public Printer's recent initiative which would test the dissemination of electronic information to depositories by providing free data tapes to private sector providers was discussed at ALA Midwinter by Joseph Jenifer, the Deputy Public Printer. The library community has expressed serious reservations about such a precedent-setting test of only one alternative. A presolicitation conference was to be held at GPO on January 19, but was postponed pending consultation with the Joint Committee on Printing. JCP has since requested GPO to develop a plan with a variety of formats and providers in time for the FY 1989 appropriations process.

A Midwinter Forum on the implications of an electronic Depository Library Program was sponsored by the ALA Legislation Committee, GODORT, ARL, COSLA, SLA, and AALL in an effort to increase the visibility of these complex issues. A major ARL task force report, "Technology \& U.S. Government Information Policies: Catalysts for New Partnerships," was discussed, as well as a GODORT committee report, "Government Information Technology and Information Dissemination: A Discussion Paper," and an ALA Legislation Committee paper commenting on the ARL report. The ARL report is available for $\$ 5$ prepaid from ARL, 1527 New Hampshire Ave., NW, Washington, DC 20036. Contact Carol Henderson at ALA's Washington Office for information on ALA documents.

In related actions, ALA Council adopted the following on January 13 during Midwinter: Resolution on Electronic Dissemination of Government Information to Depository Libraries (in (continued on p.199) 
reference services required. Good communication skills and public service orientation. MBA or equivalent degree helpful. Salary: Appointment salary will be based on qualifications and experience ( $\$ 18,750$ minimum). Comprehensive benefits package available. Apply to: Please send cover letter, resume and list of three references to: Ann Dyckman, Personnel Director, Corne11 University Library, 201 01in Library, Ithaca, NY 14853-5301. Applications requested by May 1,1988 , but will be accepted until position is filled. Background: The School of Hotel Administration Library is a unique collection, highly respected throughout the world, containing an undergraduate business collection specializing in the hospitality industries. It provides services to approximately 800 students, staff and faculty of the school as well as a fee-based service to industry executives. Cornell University is an Equal Opportunity, Affirmative Action Employer.

TECHNICAL SERVICES LIBRARIAN. Will supervise paraprofessionals in acquisitions, cataloging and serials. Oversee processing of 40,000 volume gift collection and infusion of materials during major collection development effort. Team member for selection of automated system. Two years' relevant experience required. Salary $\$ 24,000-\$ 27,000$. Review of applications began February 1. Available July 1988. Send resume and three letters of recommendation to: Office of the Provost, Shawnee State University, 940 Second Street, Portsmouth, $\mathrm{OH}$ 45662. Affirmative Action, Equal Opportunity Employer. Minorities encouraged to apply.

**********************************************************************************

(Washington Hotline, cont'd)

support of such dissemination), CD \#35; Resolution Regarding Government Information Bill of Rights (adopting the Government Information "Bill of Rights" developed by GODORT), CD \#37, with an amendment referring the 10-point "bill of rights" to ALA's Intellectual Freedom Committee for wording changes; Resolution Concerning the Privatization of Federal Libraries and Document Depositories (urging Congress to bar further contracting out), CD \#36.

\section{ACRL'S FAST JOB LISTING}

Looking for a job? Our Fast Job Listing will send you job postings received at ACRL headquarters fourweeks before they appear in C\&RL News. The Fast Job Listing Service also contains advertisements which, because of narrow application deadlines, will not appear in C $U R L N e w s$.

The ACRL office prepares a Fast Job Listing circular at the beginning of each month and mails it to subscribers first class. The circular contains all job announcements received during the previous four weeks.

The cost of a six-month subscription is $\$ 10$ for ACRL members and $\$ 15$ for nonmembers. You may enter your subscription below.

Please enter my subscription to the ACRL Fast Job Listing Service.

I am a member of ACRL and am enclosing $\$ 10$.

I am not a member of ACRL and am enclosing $\$ 15$.

NAME:

ADDRESS:

Please make checks payable to ACRL/ALA and send to Fast Job Listing Service, ACRL/ALA, 50 E. Huron ST., Chicago, IL 60611. 


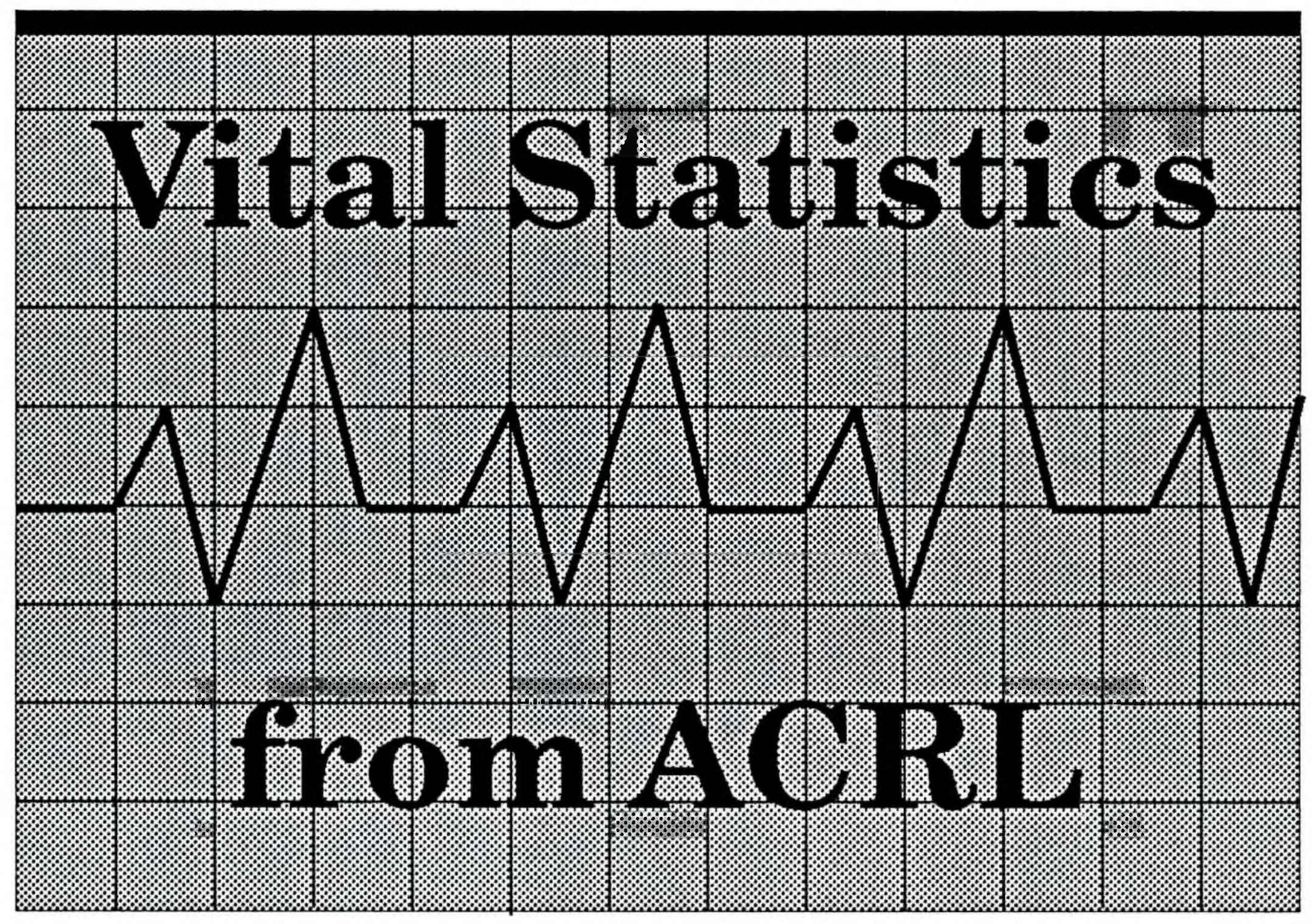

Library Statistics of Colleges and Universities, 1985:

National Summaries, State Summaries, Institutional Tables. Statistics on 3,000 academic libraries surveyed by the Center for Educational Statistics. Contains data on collections, operating expenditures, staff, and institutional indices of library operating expenditures, books and bound serials and FTE library staff. $\$ 30.00 \mathrm{pb} ; \quad$ ACRL member $\$ 24.00 \quad 240$ p. $\quad 0-8389-7147-4 \quad 1987$

\section{ACRL University Library Statistics 1985-86 and 1986 "100} Libraries" Statistical Survey. Data and rankings of 149 university, college, community and junior college libraries on collections, expenditures, personnel, and interlibrary loans.

$\$ 30.00 \mathrm{pb} ;$ ACRL member $\$ 24.00 \quad 110$ p. $\quad 0-8389-7144-\mathrm{x} \quad 1987$

Quantitative Criteria for Academic Research Libraries, by Kendon L. Stubbs. Data from 3,000 academic libraries answers the question, "What is an academic research library?" In tables arranged by state, each institution is ranked by a component score. $\$ 19.00 \mathrm{pb} ; \quad$ ACRL member $\$ 15.00 \quad 135 \mathrm{p}$. $0-8389-6788-4 \quad 1984$

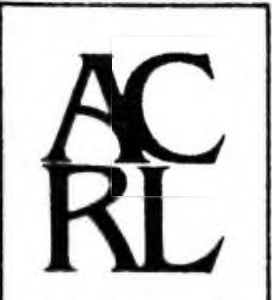

Association of College and Research Libraries A division of the American Library Association c/o ALA Publishing Services, Order Department 50 East Huron Street • Chicago, Illinois 60611-2795 